\title{
Construction of Quaternary Carbon Stereogenic Centers
}

Metal-Catalyzed Asymmetric

Synthesis and

Stereoselective

Reactions

\section{Key words}

rhodium

catalysis

allylic substitution

nitrile anion

quaternary carbon

stereogenic centers

2. $\mathrm{Rh}(\mathrm{cod})_{2} \mathrm{OTf}(5 \mathrm{~mol} \%)$ ligand $(20 \mathrm{~mol} \%)$<smiles></smiles>

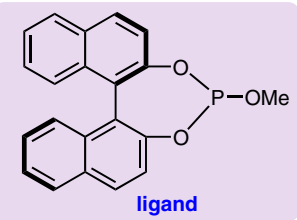

Selected examples:

$$
\mathrm{THF},-30^{\circ} \mathrm{C}
$$<smiles>C=CC[C@@](N)(Cc1ccccc1)c1ccccc1</smiles><smiles>C=CC[C@@](C#N)(Cc1ccccc1)c1ccc(OC)cc1</smiles>

$86 \%$ yield, $92 \%$ ee<smiles>C=CC[C@@](C#N)(c1ccccc1)C(C)C</smiles>

$77 \%$ yield, $92 \%$ ee

$81 \%$ yield, $84 \%$ ee

$87 \%$ yield, $83 \%$ ee<smiles>C=CC[C@@](N)(Cc1ccccc1)c1ccc(C)cc1</smiles><smiles>C=CC[C@](C)(C#N)c1ccc(C(F)(F)F)cc1</smiles>

$83 \%$ yield, $90 \%$ ee<smiles>C=CC[C@](N)(Cc1ccccc1)c1ccc(C(F)(F)F)cc1</smiles>

$81 \%$ yield, $92 \%$ ee

$76 \%$ yield, $93 \%$ ee

$82 \%$ yield, $95 \%$ ee

1. MeLi

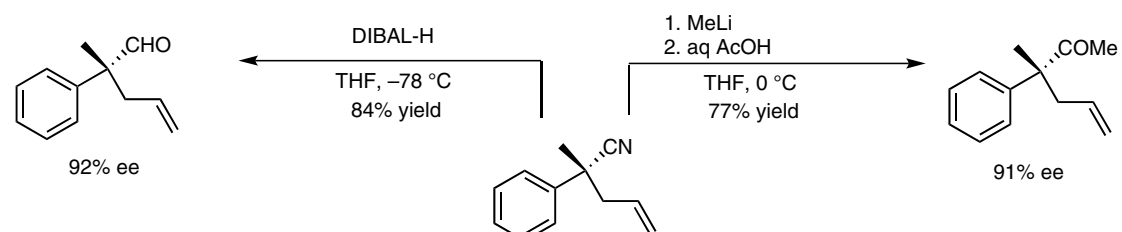<smiles>C=CC[C@](C)(CN)c1ccccc1</smiles>

$91 \%$ ee
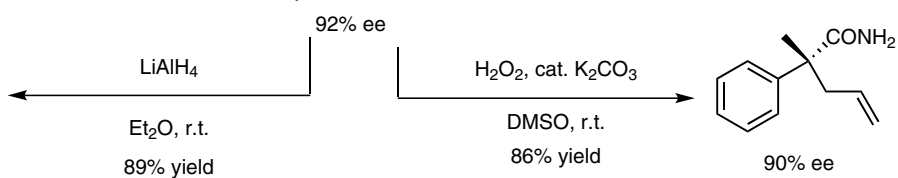

$90 \%$ ee

Significance: The enantioselective construction of quaternary carbon stereogenic centers in acyclic systems remains one of the great challenges. A highly enantioselective rhodium-catalyzed allylic alkylation of allyl benzoate by $\alpha$-substituted benzyl nitrile anions provides access to acyclic quaternary carbon stereogenic centers in good yields with excellent enantioselectivities.
Comment: Interestingly, 15-crown-5 was used as additive to provide a significant improvement in the enantioselectivity. The protocol provides a new approach for the construction of acyclic quaternary carbon stereogenic centers. Furthermore, the nitrile products can be easily transformed into a number of important derivatives. 